\title{
Arginine Grafting to Endow Cell-Permeability
}

\author{
Stephen M. Fuchs ${ }^{\dagger}, \ddagger$ and Ronald T. Raines ${ }^{\dagger}, \S$, \\ tDepartment of Biochemistry, University of Wisconsin-Madison, Madison, Wisconsin 53706, USA. \\ $\S$ Department of Chemistry, University of Wisconsin-Madison, Madison, Wisconsin 53706, USA.
}

\begin{abstract}
We report on a means to endow proteins with the ability to permeate mammalian cells without appending an exogenous domain. Our approach is to install a cationic patch on the surface of a target protein by the grafting of arginine residues. Doing so with green fluorescent protein (GFP) did not compromise conformational stability but enabled efficient cellular uptake that was dependent on cellsurface glycosaminoglycans. We anticipate that this cell-permeable variant of GFP, which obviates the need for transfection, will be useful for numerous applications in cell biology, and that the method of arginine grafting will be broadly applicable.
\end{abstract}

The plasma membrane is a natural barrier that excludes most molecules. Breaching this barrier is a limiting factor in the development of proteins and other biomolecules as therapeutics and diagnostic tools (1). Accordingly, there is much interest in developing new means to deliver proteins and other macromolecules into cells.

Small cationic peptides are capable of cellular entry, promoted best by the guanidinium group on the side chain of arginine residues (2-4). Appending polyarginine to proteins can enable uptake, but the transducing domain increases the size of a target protein and is readily susceptible to proteolysis (5). Chemical modification to supply a protein with cationic functional groups can likewise enable cellular entry $(6,7)$, but at the expense of homogeneity. Some ribonucleases are known to invade mammalian cells (8), perhaps due to a natural cluster of cationic residues on their surface (9). These precedents inspired us to use site-directed mutagenesis to modify a three-dimensional scaffold with the intent of endowing cell permeability.

As a model, we chose to employ the green fluorescent protein (GFP) from the jellyfish Aequorea victoria. GFP is a well-characterized protein (10-13) with a convenient signal for detecting cellular uptake-intrinsic fluorescence $(14,15)$. More specifically, we made aminoacid substitutions in enhanced GFP (eGFP), which is the F64L/S65T variant and has desirable fluorescence properties (16).

GFP is an acidic protein, having a net charge (i.e., Arg + Lys - Asp - Glu) of $Z=-9$ at neutral $\mathrm{pH}$. We noted that one face of GFP is variegated with acidic and basic residues (Figure 1). We chose to replace the five acidic residues (Glu17, Asp19, Asp21, Glu111, and Glu124) on this face with arginine. These acidic residues reside on three, adjacent $\beta$-strands, proximal to five basic residues (Lys107, Arg109, Lys113, Lys122, and Lys126). Hence, these five substitutions

*Corresponding author, raines@ biochem.wisc.edu.

‡Present address: Department of Biochemistry and Biophysics, The University of North Carolina at Chapel Hill, Chapel Hill, North Carolina 27599, USA.

Supporting Information Available: This material is available free of charge via the Internet. 
created a highly cationic patch on the surface of eGFP (Figure 1), yielding a nearly neutral $(Z=+1)$ variant that we refer to as cell-permeable GFP (cpGFP).

We produced cpGFP in Escherichia coli (17). Cation-exchange chromatography was especially efficacious in the purification of cpGFP, affording nearly homogeneous protein. The fluorescence properties of cpGFP were found to be nearly identical to those of eGFP (see Supporting Information).

Formation of the GFP fluorophore $(18,19)$ requires its proper folding (20). Moreover, use of GFP requires the retention of its conformational stability in biological assays. Replacing anionic residues with cationic ones can alter protein stability, though this effect is not readily predictable (21). Hence, we used chemical denaturation to ascertain the effect of arginine grafting on the stability of eGFP. We observed that both cpGFP and eGFP have unfolding midpoints at $C_{1 / 2}=(3.1 \pm 0.3) \mathrm{M}$ guanidine- $\mathrm{HCl}$ (see Supporting Information). Thus, the creation of a cationic patch did not have a deleterious effect on conformational stability.

Cellular internalization of GFP can be visualized by fluorescence microscopy $(14,15)$. Hence, we incubated HeLa cells with increasing concentrations of either cpGFP or eGFP for known times at $37{ }^{\circ} \mathrm{C}$. Prior to visualization, cells were placed in fresh medium for $1 \mathrm{~h}$ to allow for the internalization of any protein bound to the cell surface. We observed fluorescence within living cells incubated with cpGFP and found its intensity to be dose-dependent, increasing at high concentration of cpGFP (Figure 2a-c). No cytotoxicity was observed, even upon incubation with $50 \mu \mathrm{M}$ cpGFP. Although a small amount was detectable in the cytosol, cpGFP was observed primarily in vesicles. This localization is similar to that observed with cationic peptides, such as polyarginine (22). Insignificant fluorescence intensity was observed in cells incubated with eGFP (Figure 2d) or eGFP with a polyarginine appendage (23), though this latter experiment used neuronal cells and a much shorter incubation period.

Glycosaminoglycans (GAGs) such as heparan sulfate (HS) and condroitin sulfate (CS) on the cell surface can mediate the binding of cationic peptides and proteins $(22,24,4)$. To probe for a role for GAGs in cpGFP internalization, we compared cell-surface binding and cellular internalization of cpGFP in wild-type Chinese hamster ovary (CHO) cells (CHO-KI) to that in a $\mathrm{CHO}$ cell line that is deficient in GAG biosynthesis. In wild-type CHO-K1 cells, cpGFP was observed to bind to the cell surface and undergo internalization (Figure 2e). In CHO-745 cells (which are deficient in HS and CS), there is little internalization of cpGFP (Figure 2f). At a 10-fold higher protein concentration, cpGFP is internalized in the GAG-deficient cell line (see Supporting Information). Similar results were obtained with another GAG-deficient cell line, CHO-677 (data not shown). Apparently, cpGFP internalization relies largely, but not exclusively, on the interaction with cell-surface GAGs, and is efficient in both human and rodent cells displaying GAGs.

GFP and its variants are in widespread use in cell biology $(10,12,13)$. Among these variants, cpGFP is unique in obviating a need for transfection or chemical additives to infuse mammalian cells with a fluorescent protein (23), and hence could have numerous applications, both in vitro and in vivo (25). For example, some GFP variants respond to changes in the solution $\mathrm{pH}$ or reduction potential $(17,26)$. Merging such variants with cpGFP could provide a useful sensor for important physicochemical parameters within living cells. Likewise, cpGFP could serve as a component of a FRET-based substrate for assays of proteolytic or other enzymatic activities $(27,28)$. More generally, our data demonstrate that an extraneous transduction domain (2-4) is not a necessary component of a cell-permeable protein. Accordingly, we anticipate that arginine grafting could become a useful means to endow many proteins with cell-permeability. 


\section{Supplementary Material}

Refer to Web version on PubMed Central for supplementary material.

\section{Acknowledgments}

The authors would like to thank G.T. Hanson for contributive discussions and F.W. Kotch and M. Paul for advice on the manuscript. S.M.F. was supported by Biotechnology Training Grant 08349 (NIH). This work was supported by grants GM44783 and CA73808 (NIH).

\section{REFERENCES}

1. Marafino BJ Jr, Pugsley MK. Commercial development considerations for biotechnology-derived therapeutics. Cardiovasc. Toxicol 2003;3:5-12. [PubMed: 12668886]

2. Yang Y, Ma J, Song Z, Wu M. HIV-1 TAT-mediated protein transduction and subcellular localization using novel expression vectors. FEBS Lett 2002;532:36-44. [PubMed: 12459459]

3. Fischer R, Fotin-Mleczek M, Hufnagel H, Brock R. Break on through to the other side-Biophysics and cell biology shed light on cell-penetrating peptides. ChemBioChem 2005;6:2126-2142. [PubMed: 16254940]

4. Fuchs SM, Raines RT. Internalization of cationic peptides: The road less (or more) traveled. Cell. Mol. Life Sci 2006;76:1819-1822. [PubMed: 16909213]

5. Fuchs SM, Raines RT. Polyarginine as a multifunctional fusion tag. Protein Sci 2005;14:1538-1544. [PubMed: 15930002]

6. Triguero D, Buciak JB, Yang J, Pardridge WM. Blood-brain barrier transport of cationized immunoglobulin G: Enhanced delivery compared to native protein. Proc. Natl. Acad. Sci. USA 1989;86:4761-4765. [PubMed: 2734318]

7. Futami J, Kitazoe M, Maeda T, Nukui E, Sakaguchi M, Kosaka J, Miyazaki M, Kosaka M, Tada H, Seno M, Sasaki J, Huh NH, Namba M, Yamada H. Intracellular delivery of proteins into mammalian living cells by polyethylenimine-cationization. J. Biosci. Bioeng 2005;99:95-103. [PubMed: 16233763]

8. Haigis MC, Raines RT. Secretory ribonucleases are internalized by a dynamin-independent endocytic pathway. J. Cell Sci 2003;116:313-324. [PubMed: 12482917]

9. Notomista E, Mancheño JM, Crescenzi O, Di Donato A, Gavilanes J, D'Alessio G. The role of electrostatic interactions in the antitumor activity of dimeric RNases. FEBS J 2006;273:3687-3697. [PubMed: 16911519]

10. Zimmer, M. Glowing Genes: A Revolution in Biotechnology. Amherst, NY: Prometheus Books; 2005.

11. Pieribone, V.; Gruber, DF. Aglow in the Dark: The Revolutionary Science of Biofluorescence. Cambridge, MA: Belknap Press; 2006.

12. Ward TH, Lippincott-Schwartz J. The uses of green fluorescent protein in mammalian cells. Methods Biochem. Anal 2006;47:305-337. [PubMed: 16335719]

13. Zacharias DA, Tsien RY. Molecular biology and mutation of green fluorescent protein. Methods Biochem. Anal 2006;47:83-120. [PubMed: 16335711]

14. Han K, Jeon M-J, Kim K-A, Park J, Choi SY. Efficient intracellular delivery of GFP by homeodomains of Drosophila Fushi-tarazu and engrailed proteins. Mol. Cells 2000;10:728-732. [PubMed: 11211880]

15. Tanaka Y, Dowdy SF, Linehan DC, Eberlein TJ, Goedegebuure PS. Induction of antigen-specific CTL by recombinant HIV trans-activating fusion protein-pulsed human monocyte-derived dendritic cells. J. Immunol 2001;170:1291-1298. [PubMed: 12538688]

16. Cormack BP, Valdivia RH, Falkow S. FACS-Optimized mutants of the green fluorescent protein (GFP). Gene 1996;173:33-38. [PubMed: 8707053]

17. Hanson GT, McAnaney TB, Park ES, Rendell ME, Yarbrough DK, Chu S, Xi L, Boxer SG, Montrose $\mathrm{MH}$, Remington SJ. Green fluorescent protein variants as ratiometric dual emission pH sensors. 1 . 
Structural characterization and preliminary application. Biochemistry 2002;41:15477-15488. [PubMed: 12501176]

18. Cody CW, Prasher DC, Westler WM, Prendergast FG, Ward WW. Chemical structure of the hexapeptide chromophore of the Aequorea green-fluorescent protein. Biochemistry 1993;32:12121218. [PubMed: 8448132]

19. Bell AF, He X, Wachter RM, Tonge PJ. Probing the ground state structure of the green fluorescent protein chromophore using Raman spectroscopy. Biochemistry 2000;39:4423-4431. [PubMed: 10757992]

20. Waldo GS, Standish BM, Berendzen J, Terwilliger TC. Rapid protein-folding assay using green fluorescent protein. Nat. Biotechnol 1999;17:691-695. [PubMed: 10404163]

21. Pace CN, Alston RW, Shaw KL. Charge-charge interactions influence the denatured state ensemble and contribute to protein stability. Protein Sci 2000;9:1395-1398. [PubMed: 10933506]

22. Fuchs SM, Raines RT. Pathway for polyarginine entry into mammalian cells. Biochemistry 2004;43:2438-2444. [PubMed: 14992581]

23. Takeuchi T, Kosuge M, Tadokoro A, Sugiura Y, Nishi M, Kawata M, Sakai N, Matile S, Futaki S. Direct and rapid cytosolic delivery using cell-penetrating peptides mediated by pyrenebutyrate. ACS Chem. Biol 2006;1:299-303. [PubMed: 17163758]

24. Richard JP, Melikov K, Brooks H, Prevot P, Lebleu B, Chernomordik LV. Cellular uptake of unconjugated TAT peptide involves clathrin-dependent endocytosis and heparan sulfate receptors. J. Biol. Chem 2005;280:15300-15306. [PubMed: 15687490]

25. Hoffman RM. The multiple uses of fluorescent proteins to visualize cancer in vivo. Nat. Rev. Cancer 2005;5:796-806. [PubMed: 16195751]

26. Hanson GT, Aggeler R, Oglesbee D, Cannon M, Capaldi RA, Tsien RY, Remington SJ. Investigating mitochondrial redox potential with redox-sensitive green fluorescent protein indicators. J. Biol. Chem 2004;279:13044-13053. [PubMed: 14722062]

27. Heim R, Tsien RY. Engineering green fluorescent protein for improved brightness, longer wavelengths and fluorescence resonance energy transfer. Curr. Biol 1996;6:178-182. [PubMed: 8673464]

28. Pollok BA, Heim R. Using GFP in FRET-based applications. Trends Cell Biol 1999;9:57-60. [PubMed: 10087619] 


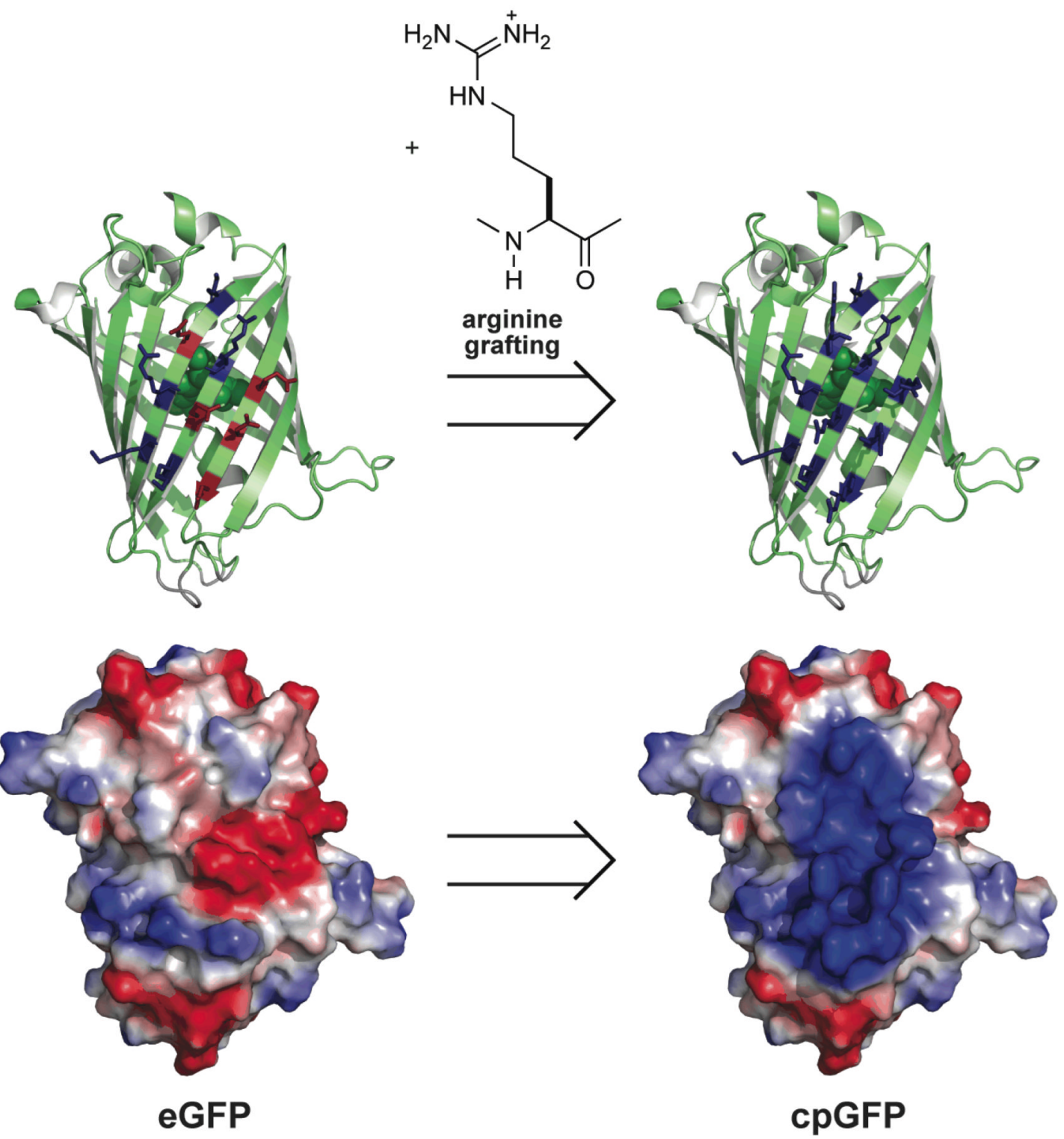

Figure 1.

Scheme for arginine grafting to create a cell-permeable variant of GFP (cpGFP). (top) Ribbon model depicting the location of the five anionic residues in GFP that were replaced with arginine to yield a surface comprised of ten cationic residues. The fluorophore is depicted in space-filling mode. (bottom) Space-filling model depicting the effect of the arginine substitutions on the electropotential surface (blue: cationic; red: anionic). 

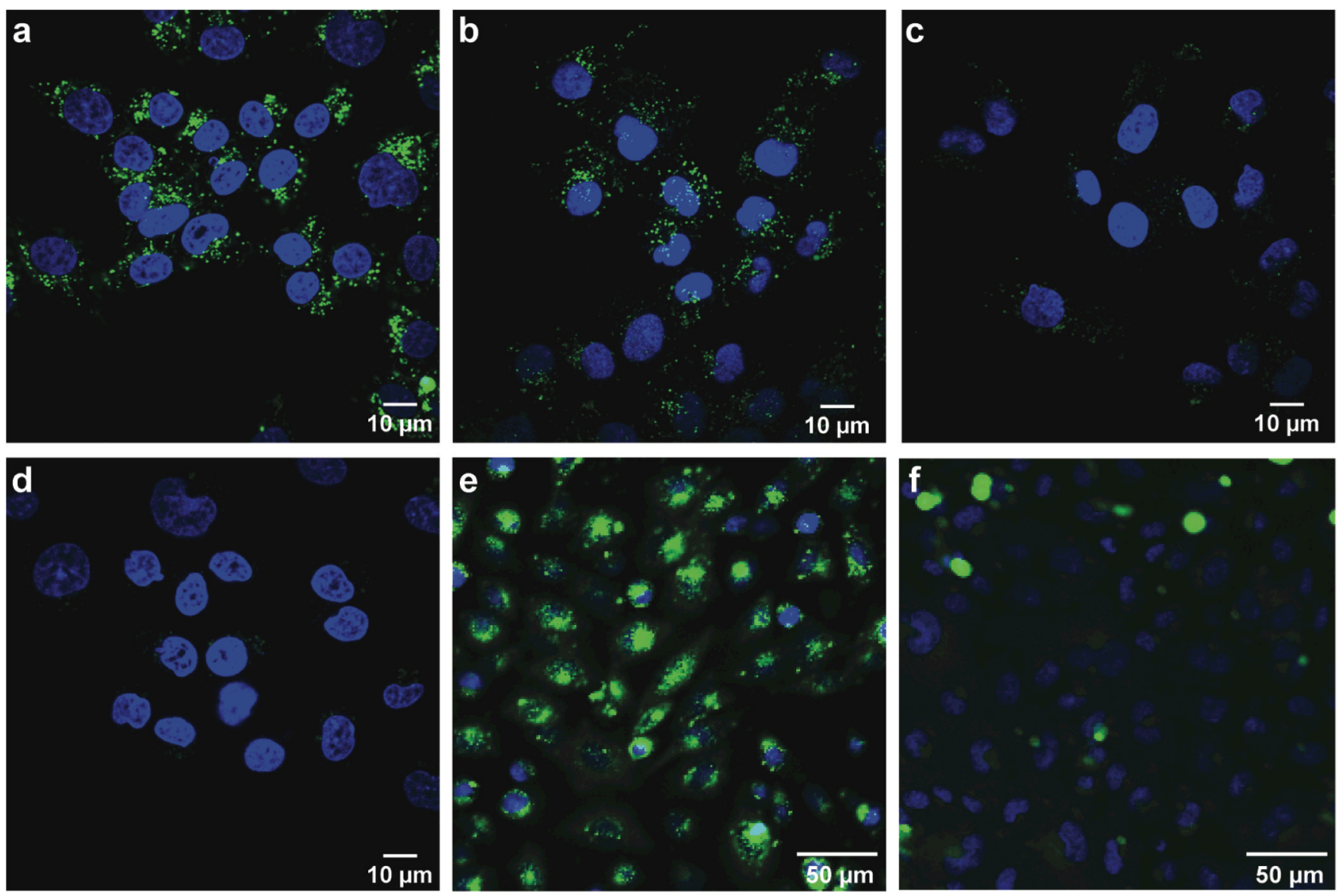

Figure 2.

Images of the internalization of GFP variants into living human and rodent cells. HeLa cells were incubated with cpGFP $(\mathbf{a}, 10 \mu \mathrm{M} ; \mathbf{b}, 1 \mu \mathrm{M} ; \mathbf{c}, 0.1 \mu \mathrm{M})$ and eGFP $(\mathbf{d}, 10 \mu \mathrm{M})$ for $3 \mathrm{~h}$ in Opti-MEM medium at $37^{\circ} \mathrm{C}$. Cells were then placed in fresh medium for $1 \mathrm{~h}$ and stained with Hoescht 33342 (blue) and propidium iodide (red) for $15 \mathrm{~min}$ prior to visualization by confocal microscopy. (e) CHO-K1 and (f) CHO-745 cells (which are GAG-deficient) were incubated with cpGFP $(2 \mu \mathrm{M})$ for $3 \mathrm{~h}$ at $37^{\circ} \mathrm{C}$ in Opti-MEM medium. Cells were then placed in fresh medium for $1 \mathrm{~h}$ and stained with Hoescht 33342 (blue) and propidium iodide (red) for $15 \mathrm{~min}$ prior to visualization. 